\title{
CONSUMER CURRENT TRENDS IN RESTAURANT INDUSTRIES: A CASE STUDY OF FOOD BLOGGER
}

\author{
${ }^{1}$ Esa Mbouw, ${ }^{2}$ Khansa Qonita
}

\begin{abstract}
The trend of food and beverage industry in Indonesia has shown a great transformation with a help from the current existing technologies. A food related blog is one the trend these days, especially for the millennial. Perceived Usefulness (PU) is one of the factors suggested by researches towards adaptation of technology. However, the perceived usefulness of a food blogger itself is still questioned on whether the millennial has the intention to follow the food blogger's recommendation to choose restaurants. Therefore, the purpose of this study is to determine whether there is a significant relationship between food blogger perceived usefulness and behavioral intention to follow its recommendation. The questionnaire was distributed to 100 food blog readers who have read any food related blog before. The data was processed by using SPSS to obtain the result of this study. The result has shown that food blogger influences the consumer behavioral intention of the readers to follow its recommendation of the food blogger.
\end{abstract}

Keywords: Perceived Usefulness, Food Blogger, Behavioral Intention to Follow 


\section{Introduction}

For the past few years, blogging has become one of the media that specially attract the millennial. By using blog people can share their journey, opinion, reviews, feeling, and thought in everyday life (Hanifati, 2015). The idea is that it does not have to be specific with only certain subject but it can be anything associated with the blog writer's idea and the theme. Blogs are Internet sites where individuals post their thoughts, ideas, and inspirations online in an unedited and spontaneous style (Crewe, 2013). Blogs have now changed our perception about the world around us and food blogging is an emerging subject matter in blogs (Philip, 2016). In 2015 there were 89 million people accessing the internet and as in 2016 there were 97 million internet users. The number keep increasing in 2017 with 104 million internet users and 112 million users in 2018.Starting from October 2006, there are 35.8 million blogs and it doubles their number by 61.4 million blogs on October 2007. The number kept on steadily rising on 2008 by 78.7 million blog and rises by 127 million blogs in 2009. Until the last point of 2011 the numbers of blog keep on rising until now. A food blogger shares recipes, places to eat (food trip), and share their opinion on restaurants they have visited. Furthermore, they also feature images, short videos, and information regarding the restaurant itself. Besides, a food blogger did not only use blog as their media some are using and linked to other several social media related to their blog, such as Instagram and YouTube. A blogger understands that words can influence not only the current audience, but also future audiences (Evans, 2010). According to (Syed, 2017) a study has stated that $92 \%$ of consumers trust recommendations from other people (relatives or friends) or even individuals they don't know. As food bloggers are recently become the influence for food and beverage industry, businesses and restaurants are aware and is taking the advantage of their presence to review their products and as well as the restaurant itself. Most of the food blogger write a long paragraph to share their opinion about restaurants they had visited. Unfortunately, since a food blogger becoming the trend within the millennial, there are many of newcomers that write food related blog. By which the readers need to find out which of these food bloggers they have to follow the recommendation.

\section{Literature Review}

\subsection{Marketing}

Kotler and Keller (2006) explain that marketing is refer to discover and meet the human necessity as well as the social needs. While a brief definition for that is "meeting needs profitability". Additionally 
(Kotler and Armstrong, 2016) define marketing as the process of a company creating value for their customer to build a strong relation within the targeted customer and the company to take the value from customers in return because people believe that marketing work as only selling and advertising. (Kotler, et al, 2005) interpret that marketing is a group of people or an individual obtain their needs and wants by creating and exchanging products as well as value with others.

\subsection{Marketing Mix (4PS)}

(Kotler, et al, 2005) define marketing mix as the set of marketing tools that is use by a company to create their targeted market. The marketing process involves the four decision-making variables within the circumstances of the company's macroenvironment, while focusing on the market that has been targeted by the company. The marketing mix is controlled by the company, while the macro-environment cannot be directly controlled. The main objective for the company is to determine a "mix", for each product, that can make consumer satisfy and fulfill their wants and needs while the company must be able to maintain their unique position in the marketplace (Bonjanic, 2008).

\subsection{Digital Marketing}

According to (Otero and Rolan, 2016) digital marketing is defined as a forecast of marketing, in the internet. In fact, today's digital technologies, from Web sites and online social networks to cell phones, have empowered consumers and made marketing a truly interactive affair (Kotler and Armstrong, 2016). Rather than a conventional marketing, digital marketing has become a new phenomenon that brings together customization and major distribution to accomplish their marketing goals. The development of digital marketing has offer a great potential for not only a brand but as well as organizations or company (Machado and Davim, 2016).

\subsection{EWOM (Electronic Word of Mouth)}

According to (Kotler and Armstrong, 2016) word of mouth has the powerful impact on consumer buying behavior. The meaning of electronic word of mouth itself is a recommendation or any of personal word of trusted associates, family, friends, or other trusted sources of information. In another word, word of mouth is also known as sharing information to other people about one's (Blackwell, et al, 2012). 


\section{$2.5 \mathrm{Blogs}$}

Blogs (from the term Web logs) are Web sites where entries are listed in reverse chronological order and readers can comment on any entry (Strauss and Frost, 2014). A blog can be defined as an online journal which is typically written by individuals or groups of people that feature commentary and share for their audiences (Lee, 2013).

\subsection{Technology Acceptance Model}

In 1986 Davis was first introduced Technology Acceptance Model. Technology Acceptance Model is an adaptation of the Theory of Reasoned Action (TRA). According to TRA, a person's performance is determined by his or her behavioral intention (BI) to perform the behavior, and $\mathrm{BI}$ is jointly determined by the person's attitude (A) and subjective norm (SN) concerning the behavior.

\subsection{Consumer Behavior}

Consumer behavior is defined as activity that related to people from finding, choosing, buying, using, and evaluating the product or services (Blackwell, Miniard, and Engel, 2012). When buying a product or services consumers are basically influenced by psychological characteristic, cultural, personal and social. Consumer behavior is considered as the reasons of why an individual and social shop for product, buy, use and dispose them.

\subsection{Buyer Decision Process}

The buying process of consumers need to pass through the five stages of buying decision process. The five stages consist of need recognition, information search, evaluation of alternatives, purchase decision, and end with post purchase behavior. Based on the study of (Kotler and Armstrong, 2016), the marketers need to focus on the decision process rather than the focusing on purchase decision only.

\subsection{Behavioral Intention}

In the study of (Zeithaml, Berry, and Parasuraman, 1996) behavioral intentions include word of mouth, loyalty behavior, repurchase intention, and price sensitivity. As this study analyzing about behavioral intention to follow, therefore (Hsu, Lin, \& Chiang, 2013) define behavioral intention to follow is "the degree to which blog readers believe that they will shop again online". While based on (Hanifati, 2015) behavioral intention to follow can be defined as the degree of blog reader's intention to follow food blogger recommendation in the future.

\section{Research Method}

This study will conform using descriptive research. The term descriptive research refers to the type of research question, design, and data analysis that will be use to a given topic (Knupferand and McLellan). Descriptive research can be either 
quantitative or qualitative, and this study is a quantitative analysis that will be conducted by using descriptive research, which is survey, case study, and observational. Beside quantitative, this research also a qualitative method because this study used direct interview with the food blogger to obtain the research problem. The concept of descriptive study is to find out the terms "what is". Therefore, ideally survey and observational methods are commonly used to collect the data (Knupfer and McLellan). This research will be conducted in Indonesia. This research targeting all food blog readers, specifically a person who read blogs from the website blog. This study to analyze the consumer behavioral intention to follow affected by food blogger's recommendation. Therefore, this research will observe the readers point of view on whether food blogger's recommendation affect in choosing reader's restaurant. The observed respondents in this research will be food blog readers located in Indonesia. The population covers all the millennial who are frequently read food blogs. The sampling method that will be used for this study is non-probabilistic sampling. The fact that this research would be a quantitative research, the sampling method would be random sampling method. Simple random sampling method is used due to the fact that all the food blog readers have equal opportunities of becoming the samples. Therefore, this research will be using the simple random sampling.

\section{Result and Discussion}

The total numbers of the respondents for the post test are 70 respondents. The minimum number of respondent according to Rao Purba's equations are 68. There are 70 questionnaires distributed to the possible 70 respondents. From the results in above figure, the respondents are $71 \%$ female respondents and $29 \%$ male respondents. It is shown that the majority reader of food blogger is female, all of the respondents are on their 17 to 25 years old. There are $77 \%$ of the respondents who are currently on their bachelor degree program. $21 \%$ of the respondent are having their Diploma background, while the other $2 \%$ just graduated from High School. 99\% of the respondent are students. While 1\% of the respondent is an entrepreneur or self-employed. According to the data above $63 \%$ of the respondent has their monthly income/allowances of $\mathrm{Rp}$ $2.500 .001-\mathrm{Rp} 3.000 .000$ every month. $26 \%$ of the respondents has their monthly income/allowances $\mathrm{Rp} 2.000 .001-\mathrm{Rp}$ 2.500 .000 every month. Another $7 \%$ of respondent appoint above $\mathrm{Rp} 3.000 .001$ and 4\% select Rp 1.500.001 - Rp 2.000.000 every month. The Result of 
figure shows that $97 \%$ of the respondents dine out one to three times a week, which is still consider normal. While the $3 \%$ of the respondents regularly dine out four to six times a week. Based on the results $71 \%$ of the respondents spend $\mathrm{Rp} 300.001-\mathrm{Rp}$ 500.000 when dining out. $26 \%$ of the respondents spend less than $\mathrm{Rp} 300.000$ while other $3 \%$ spend more Rp 500.001 Rp 750.000 weekly. The hypothesis of this study is as listed below:

$\mathrm{H} 1_{0}$ : Perceived usefulness of food blogger's recommendation has no significant influence towards consumer's behavioral intention to follow its recommendations.

$\mathrm{H} 1_{1}$ : Perceived usefulness of food blogger's recommendation has significant influence towards consumer's behavioral intention to follow its recommendations.

The result of the of this research is that perceived usefulness of food blogger's recommendation has no significant influence toward consumer's behavioral intention to follow its recommendation. However, this result has different result from the previous study who has stated that perceived usefulness of food blogger's recommendation has significantly influenced consumer's behavioral intention to follow its recommendation. The focus of this research is a person who read the blog from the website blog while the previous research generally uses more than one platform of media, such as Instagram. Therefore, it is not surprise that the results can be different from the previous study.

\section{Conclusion}

In summary, the objective of this research is to determine whether there is a significant relationship between food blogger's perceived usefulness and behavioral intention to follow. The dimensions of perceived usefulness are saving time, useful information, and effectiveness. The unit analysis of this research is Indonesian Food Blogger and the respondents are millennial who have read food related blog from the website. There are 100 questionnaires collected for the purpose of this study. The questionnaires were analyzed by using SPSS version 24. Conclusions of this study as followed: According to the results there are no significant relationship between perceived usefulness and behavioral intention to follow level by $25,8 \%$. Which means what perceived usefulness influences behavioral intention to follow by only $25,8 \%$. It can be concluded that perceived usefulness of food blogger does influence behavioral intention to follow by $25,8 \%$ and the rest of $74 \%$ are from another possible factors. There are 3 dimensions of perceived usefulness that 
used in this work, which are saving time, useful information and effectiveness.

\section{References}

Blackwell, R.D., Miniard, P.W., and Engel, J.F. (2012). Consumer Behavior. Singapore: Cengage.

Bonjanic, D. (2008). Handbook of hospitality Marketing Management. London: Routledge.

Crewe, L. (2010). When Virtual and Material Worlds Collide: Democratic Fashion in The Digital Age. The Environment and Planning A, 45, pp.760-780.

Evans, L. (2010). Social Media Marketing: Strategies for Engaging in Facebook, Twitter \& Other Social Media. U.S.A: Que.

Hanifati, A.N. (2015). The Impact of Food Blogger toward Consumer's Attitude and Behavior in Choosing Restaurant. International Journal of Humanities and Management Sciences, 3(3), pp.149-154.

Hsu, C.L., Lin, J.C.C., and Chiang, H.S. (2013). The effects of blogger recommendations on customers online shopping intentions. Journal of Social Sciences, 23, pp.70-88.
Knupfer, N.N., and McLellan, H. (s.a.). Research Methodologies in Educational Communications and Technology. Available from: http://members.aect.org/edtech/ed1/ind ex.asp.

Kotler, P., and Keller, K.L. (2006). Principles of Marketing. Harlow: Pearson.

Lee, E. (2013). Impacts of Social Media on Consumer Behavior - Decision Making Process. pp.1-77. Available from:

https://www.academia.edu/7336609/Ba chelors_thesis_Impacts_Of_Social_Me dia_On_Consumer_Behavior_Decision _Making_Process

Machado, C., Davim, J.P. (2016). MBA Theory and Application Business and Management Principle. London: Springer.

Strauss, J., Frost, R. (2014). E-Marketing. England: Pearson.

Philip, L. (2016). Impact of Food Blogs on The Readers. Journal of Mass Communication and Journalism, 6(2), pp.1-3.

Syed. (2017). How are Food Bloggers Turning into Influencers and Changing the Foodscape? Retrieved March 28, 
2018, from Indus Net Technologies:

https://www.indusnet.co.in/food-

bloggers-turning-influencers-changing-

foodscape/.

Zeithaml, V.A., Berry, L.L., and

Parasuraman, A. (1996). The

Behavioral Consequence of Service

Quality. Journal of Marketing, 60,

pp.31-46. 